\title{
Landscaped Estimation of the Ancient Mercuriferous Career Potentialities in the Algerian Northeast for Its Bio-Restoration
}

\author{
Fadel Djamel, Abdemadjid Sadek, Latrèche Filali and Azouz Mounir \\ Institute Agro-veterinary \\ Laboratory Science and Technology of life - University of Souk - Ahras - Algeria \\ Author corresponding: fadeldjamel@ymail.com
}

\begin{abstract}
The bio-restoration project of the mercurial career of Guenicha zone operating in the region of Azzaba must not only take into account the potential of the site but also its integration into the surrounding landscape. To achieve this result we performed a qualitative estimation of the potentialities of the site to understand better the structuring of the space and these various affectations. We took into account the current occupation of grounds to locate the precious elements, the curiosities susceptible to remain constant in the landscape and to highlight sectors or zones of an exceptional fragility which we call "sensitive sectors or zone" where any intervention can influence the visual atmosphere of the landscape. The zoning allowed us to reveal two landscaped bulks represented by the plain of Azzaba and the career of Guenicha. At first time we identified their components. To increase the visibility of the site, we shall create the dominances which characterize them and we arrange the transitions between them. In the last we will link the study area with the surrounding landscape by offering the most sensible choice of a pardon to restore the soil and also achieve the integration with the surrounding landscape.
\end{abstract}

Keywords: Visual Field of View Points, Landscape unit, Azzaba, Algeria

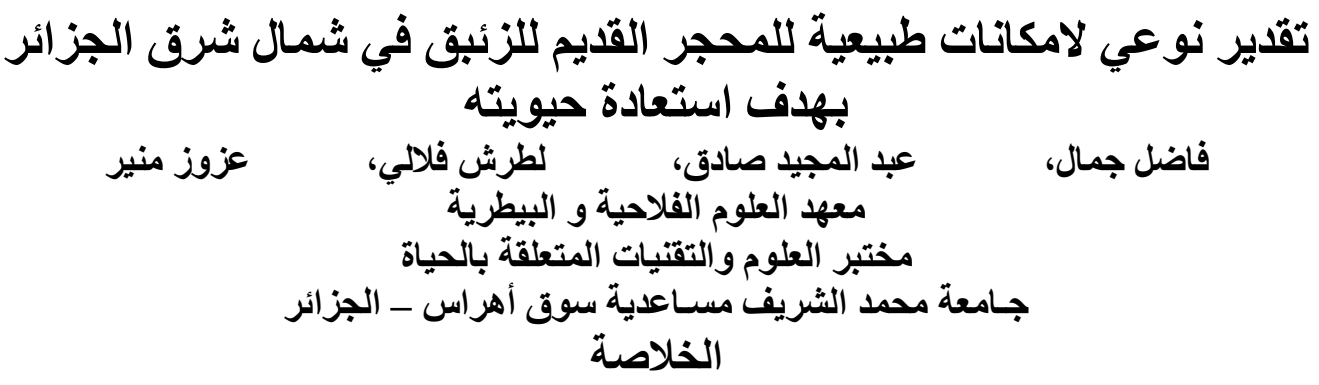

لايتطلب مشروع التأهيل الحيوي لمحجرغنيتشا (chaGueni) الواقع في موقع التعدين الزئبقي في منطقة عزابة إنة إنمانة

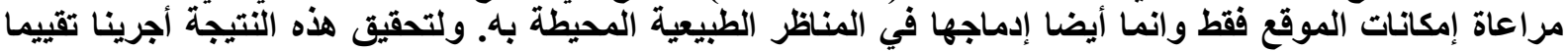

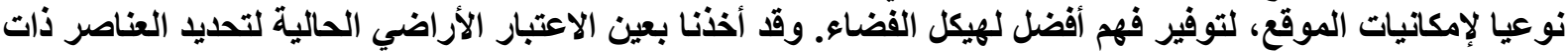

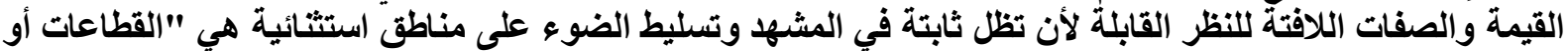

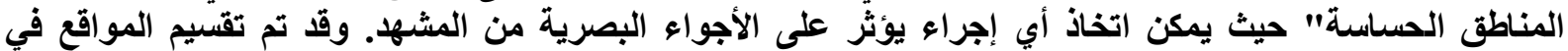

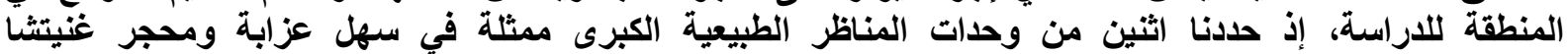
(Guenicha)

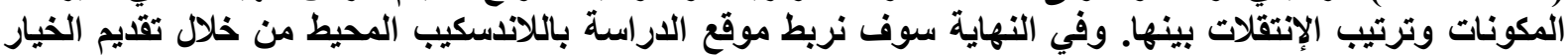

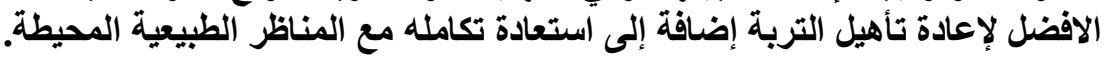

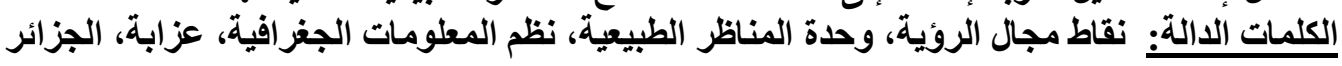

Received: $10-3-2013$

Accepted: $23-10-2013$ 


\section{Introduction}

Mining activities have impact on the environment. Apart from the negative aesthetic impact, sites abandoned have neither land nor vegetation. They are highly subject to erosion that may become a source of pollution for the whole region. Such a situation is typical of the region of Skikda. Indeed, in this region there are deposits of mercury situated in the daira of Azzaba where there is a factory of extraction of the ore the cinnabar. After their operating quarries are abandoned, in addition to human and social problems they cause leaving behind them a latent source of pollution and a degraded landscape in all its components (water, soil, vegetation). Thus, deposits and Mra -Sma, Guenicha, are leaving behind abandoned real "gaping wounds" not well integrated into the surrounding natural landscape, offering a sad spectacle and a true "visual pollution" aesthetically very badly felt. For all these reasons, the proposed restoration of the bio-career Guenicha becomes imperative. To achieve this objective it is essential that an estimation of the potential landscape of the site in view of the landscape criteria in order to integrate the surrounding landscape [1, 2, 3, 4]. As part of our work we used a qualitative approach that is based only on the components or elements that shape the landscape, having an influence on its evolution. This method is based on our visual impressions of structural elements from the site of two parameters: the views and the visual field. It uses criteria and easily identifiable elements having a real impact on the assessment of its potential $[(5,6,7$, and 8$]$. These various elements or components may be mapped.

\section{Characterization of study site}

Guenicha's career is about 04 kilometers southwest the city of Azzaba. The geographic coordinates are:

- $7^{\circ} 3^{\prime}$ East longitude;

- $36^{\circ} 42^{\prime}$ North latitude.

The territory of the study site is located on hills with very few mountains. Elevations range from 120 to about $200 \mathrm{~m}$ near the valley and can sometimes reach $300 \mathrm{~m}$ in areas of the watershed. It is approximately $500 \mathrm{~m}$ north of the valley of Oued Guenicha. It covers an area of more than 115 hectares (Fig.1).

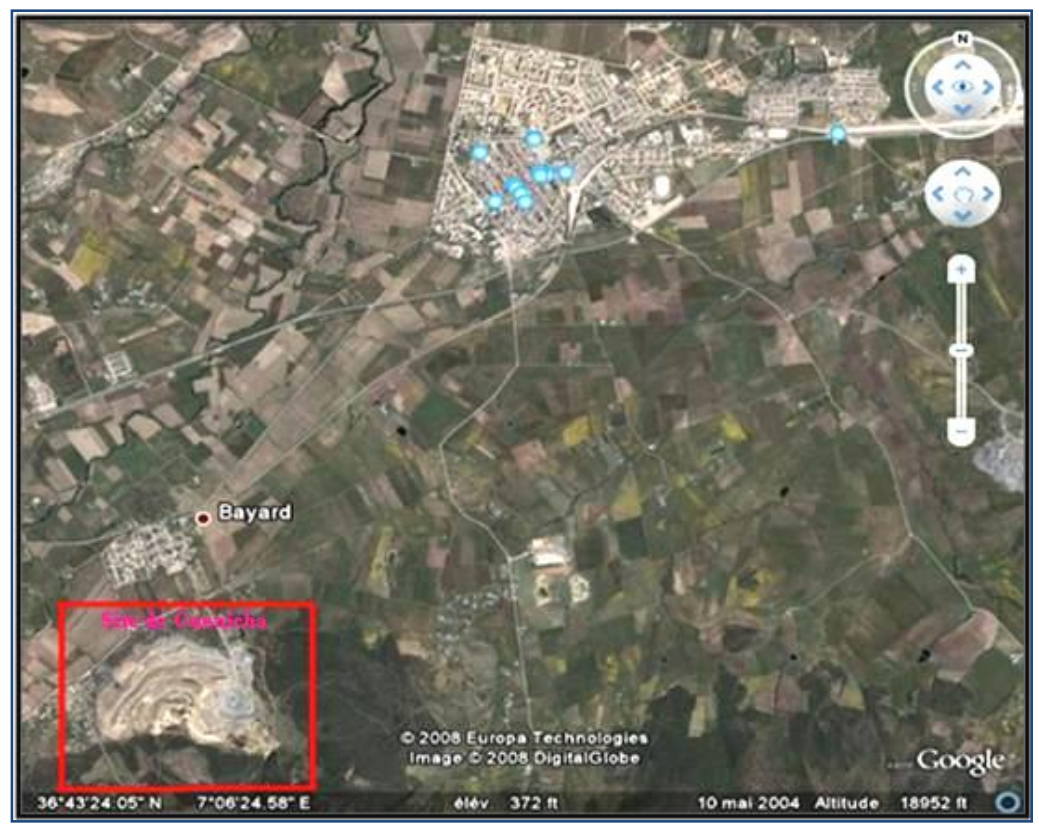

Figure 1 - Location of the study area 
The site Guenicha which has a former general appearance of conical hill with Front and Back (cuesta), is part of all the surrounding mountains. Terms of its geomorphology, the ridge line is

oriented from west to east between the site and in two sides:

- North slop

- South side.

They are the slopes of erosion and are often subjected to soil movement or have distinguished several forms of erosion (Fig. 2).

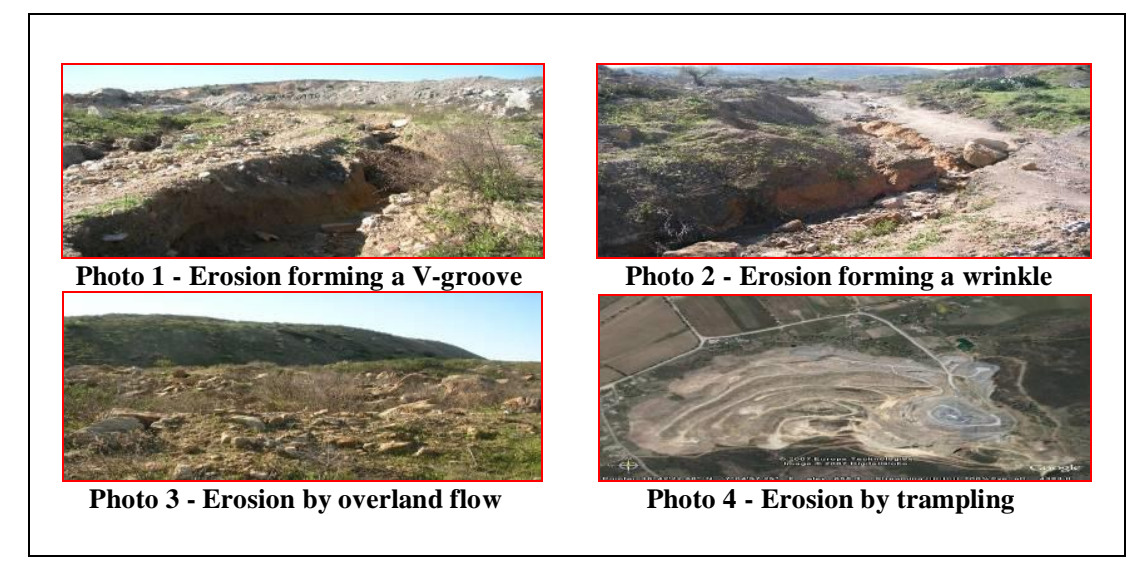

Figure 2 - Different forms of erosion

\section{Method and means of study}

Our method is based on a study of zoning in the area several landscape units defined by the following criteria:

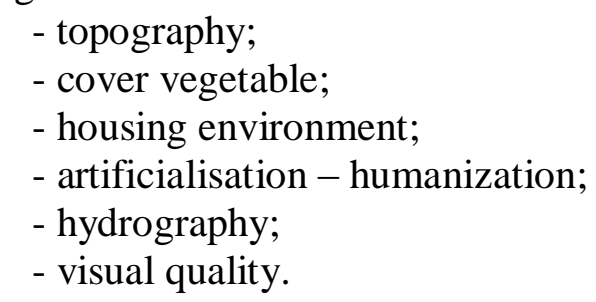

This method was also used by Fadel and Griselin [9, 10] for studies of visual landscapes. After highlighting the large sets, we have undertaken an internal analysis that identifies the components of different subunits. The external analysis, conducted from neighboring areas allows us to structure the site. The criteria that were necessary to the apprehension of the subsets are:

- Ground discovery, access, accident or natural human actions;

- Variation of the visual field which is defined as;

- Identification of the highlights to be taken into account when planning;

- Inventory of areas in which characters are to strengthen the elements for meaningful and to minimize the degrading elements.

The study was carried out on land and required a visual medium which is very appreciable photography from multiple viewpoints. To implement this study, we set in place a pedestrian on roads outside the area in question for the best view. We also used existing paths to stroll inside the area to better understand the structure of the site and address details. 
All of these operators that we have identified will form the basis of study to consider the specific uses for each unit based on their characters and their sensitivity [11, 12].

\section{Making practice and discussions}

The study area has a topographic heterogeneity which allowed us to distinguish two main landscape units:

- A lower part represented by the plain for agricultural;

- A mountain formed by several hills, including among others the site to be rehabilitated than Guenicha (Fig.3).

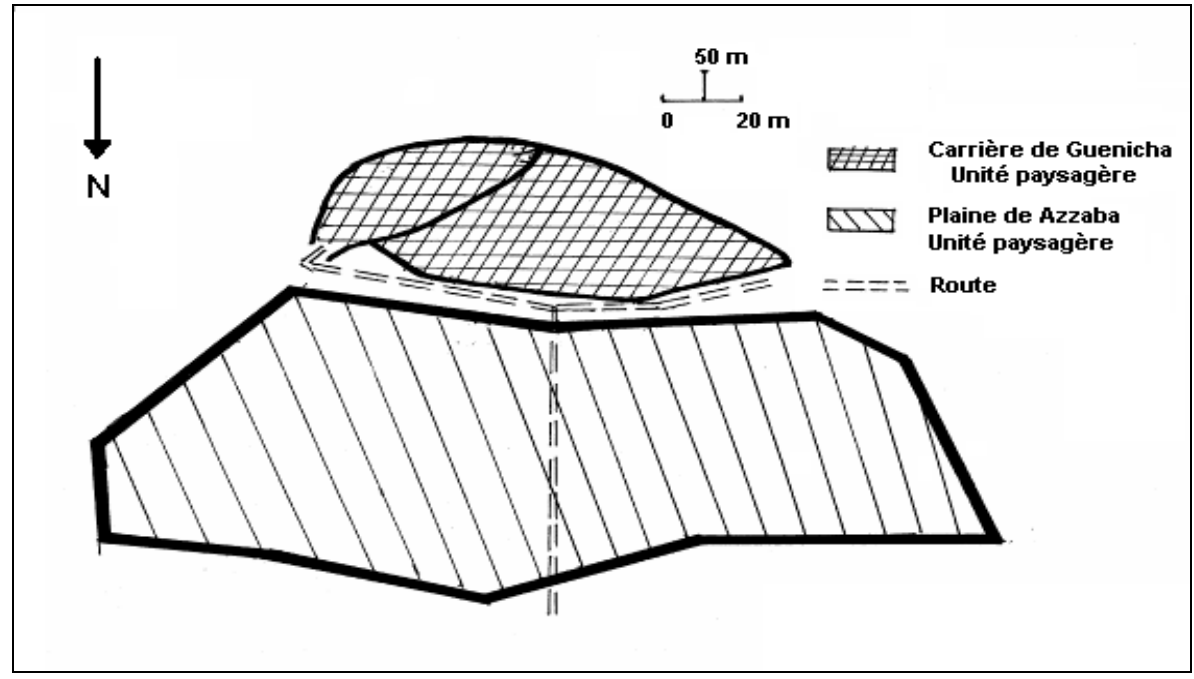

Figure 3 - The landscape units of the study area

\subsection{Selection of views and their characteristics}

The choice of location and their number remains necessarily subjective, but requires the opening of the visual field that allows the observation of the landscape [13, 14]. These views can be located both inside and outside the study site from communications paths, ridge lines, places of houses etc. and three views are needed for themselves due to the opening of their visual field as well as the study site on the surrounding landscape (Table 1).

Table 1 - Characteristics of visual fields

\begin{tabular}{|c|c|c|c|}
\hline Points of view & $\begin{array}{c}\text { Nature views of the } \\
\text { visual field }\end{array}$ & $\begin{array}{c}\text { Direction of the } \\
\text { visual field }\end{array}$ & $\begin{array}{c}\text { Openness visual field } \\
\left({ }^{\circ} \mathbf{C}\right)\end{array}$ \\
\hline $\mathrm{N}^{\circ} 1$ & Open & $\mathrm{N}-\mathrm{E} ; \mathrm{N}-\mathrm{O} ; \mathrm{S}-\mathrm{E} ; \mathrm{S}-\mathrm{O}$ & 360 \\
\hline $\mathrm{N}^{\circ} 2$ & Open & $\mathrm{N}-\mathrm{E}$ et S-E & 180 \\
\hline $\mathrm{N}^{\circ} 3$ & Open & O et S-O & 90 \\
\hline
\end{tabular}

\subsubsection{The lower part (plain)}

Because of its flatness homogeneous, the plain presents overall uniformity. This landscape unit is characteristic and easily identifiable by its components. It has several landscape units in figure 4. 


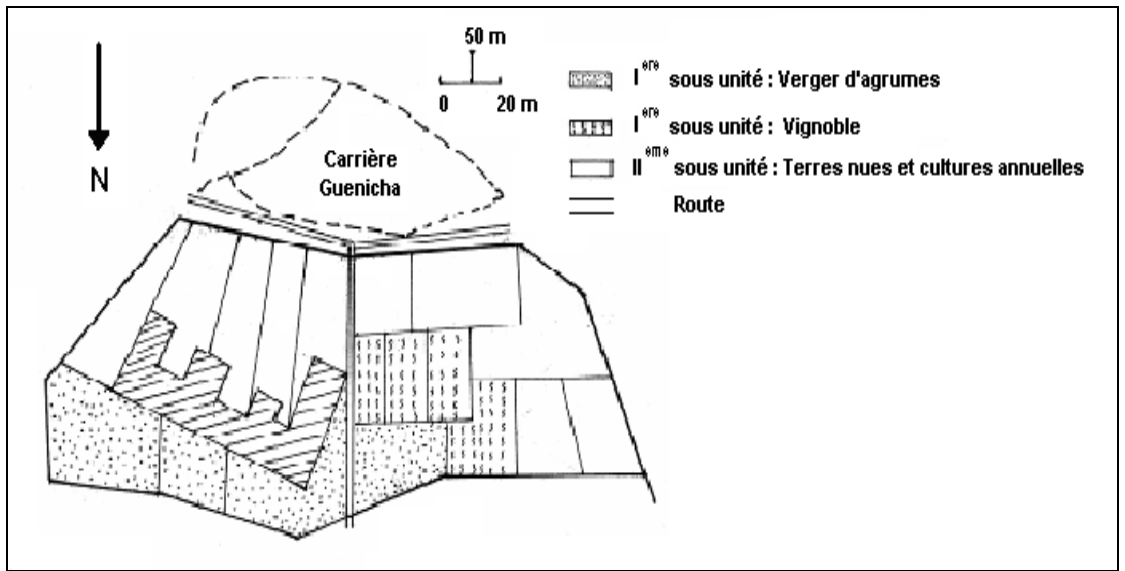

Figure 4 - The subunits of the lower (plain)

\subsubsection{Orchards}

They are the first identifiable. This tissue occupied by perennial crops composed by citrus and vines present:

- No relief due to the relatively uniform height of trees;

- A heterogeneous structure generated by the presence of several species trees; - Outside its limits appear regular and contrast sharply with the fabric and agricultural annual crops

- Inside the citrus orchard, the visual field is closed because the peaks these trees are an obstacle. By cons, the visual field remains semi opened inside the vineyard.

\subsubsection{Farmland}

On arable land bare and those involving annual crops, gives an impression of monotony that its limits are not seen:

- They are irregular over the entire

- And no relief

- Homogeneous structure

- Open visual field.

We note in this landscape unit that the provision and distribution of plant material has been instrumental in the change in the visual field that was either closed or open or half open

(Fig.5).

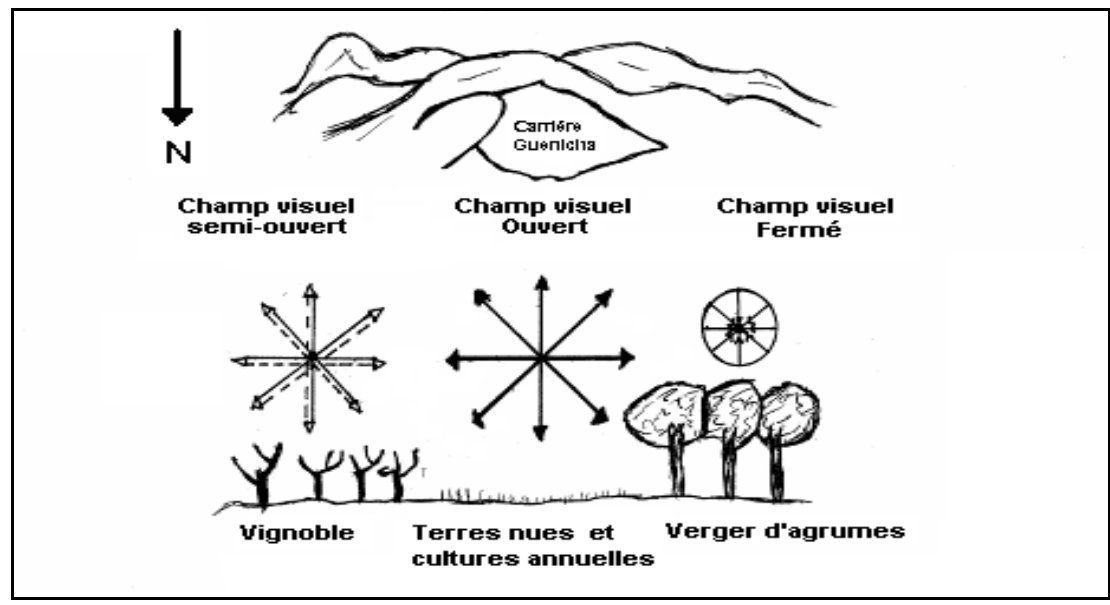

Figure 5 - Visual fields of the lower (plain) 
Changes in vegetation may change the visual field Grairi, Soualem and Hameg [15, 16, 17].

- When the vision is closed; the light is blocked and can extend the immediate vicinity with a perception of details [18]. A within the orchard of citrus plantations were dense, forming a visual barrier (photos 5 and 6 in figure 6);

- When the vision is open, we have a perception distant $[19,20]$. The break between on the one hand the woody vegetation consists of the citrus orchard and vineyard and annual crops and also worked in the fields and bare, allows us a vision and surface spreading of our views. The most distant appear to us by their volume (Guenicha quarry and the mountain range of djebels Koudia Sma, and Ferfour Regouat Lessouad. As against the closest elements are better understood (photos 7, 8 in figure 6);

- When the visual field is half open, our perception becomes confused. It retains stealth volumes of the most remote and sends us back immediately on the details of the landscape elements close (photos 9 and 10 in figure 6).

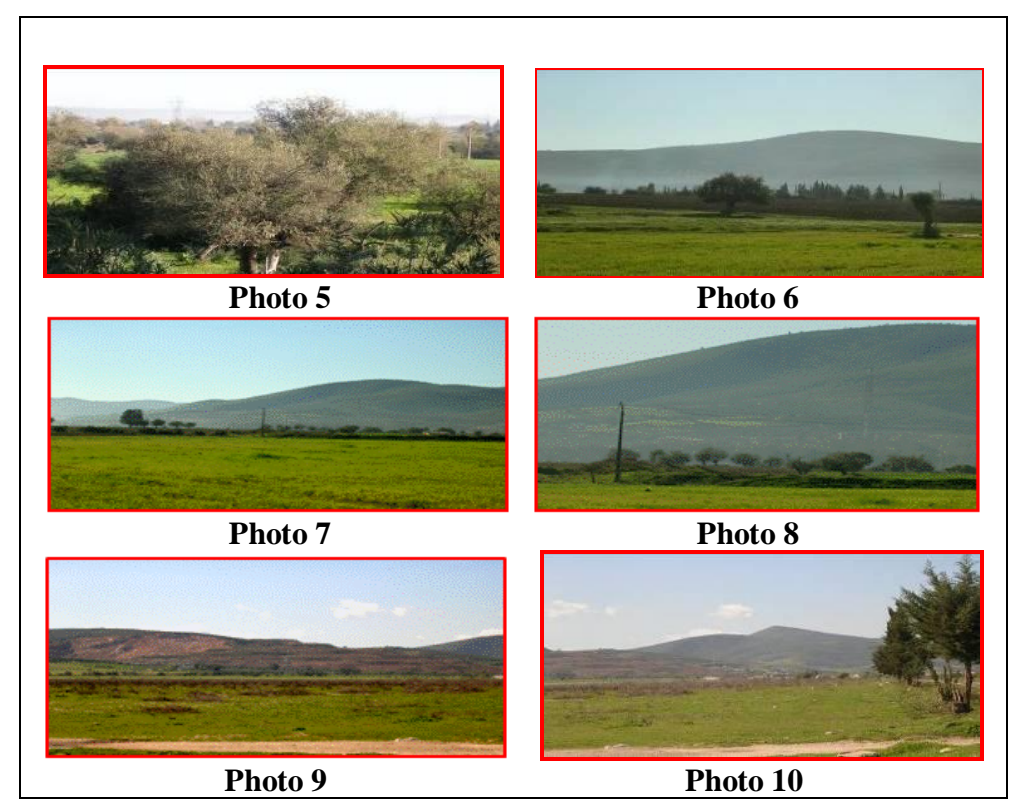

Figure 6 - Points of view of the lower (plain)

\subsubsection{Middle mountains: the case of career Guenicha}

The site of the career of Guenicha who was a former general appearance of conical hill with Front and Back (cuesta), is part of all the surrounding mountains. This landscape unit is very characteristic and easily identifiable by its different components: topographic and visual exposure. In human action and natural erosion, the site or quarry Guenicha splits into two main areas according ridgeline oriented from west to east (Fig.7). 


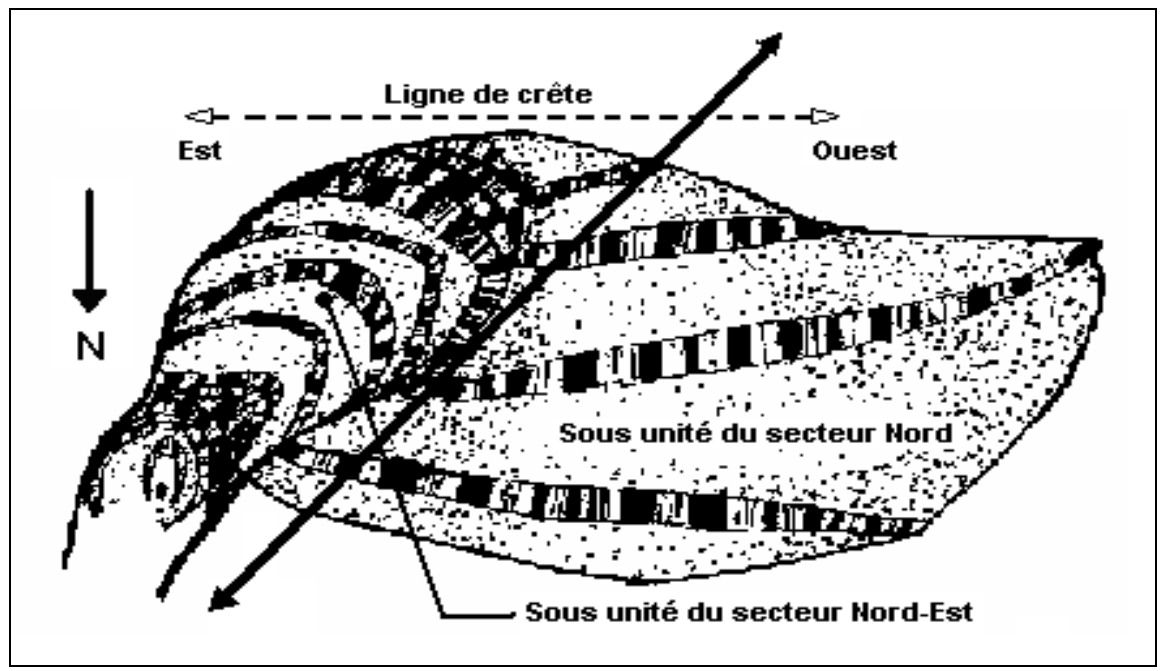

Figure 7 - Appearance of the geomorphological career Guenicha

The north sector facing the plain landscape unit is completely upset by anthropogenic stresses due to the extraction of cinnabar. In this sector, the contrasts are increasing by the game's terrain, the difference in vegetation, changes in the visual field. It is characterized by:

- Lack of housing;

- Poverty of vegetation;

- Severe erosion.

The extension of the northern subunit results in a particular landscape north - east. This sector is extremely eroded in the human and natural. It has impressive cliffs. The chasm formed in this subunit creates a break with the other space where the difficulty of physically connecting pathways by Its lower part is extremely deep allowed the accumulation of runoff thus constituting an important body of water which adds value to this sector (photo 11 in figure 9). The crest of this great landscape unit is of highly significant points of view and form a fringe so exhilarating panoramic visual field with an open $360^{\circ} \mathrm{C}$ (Fig.8.).

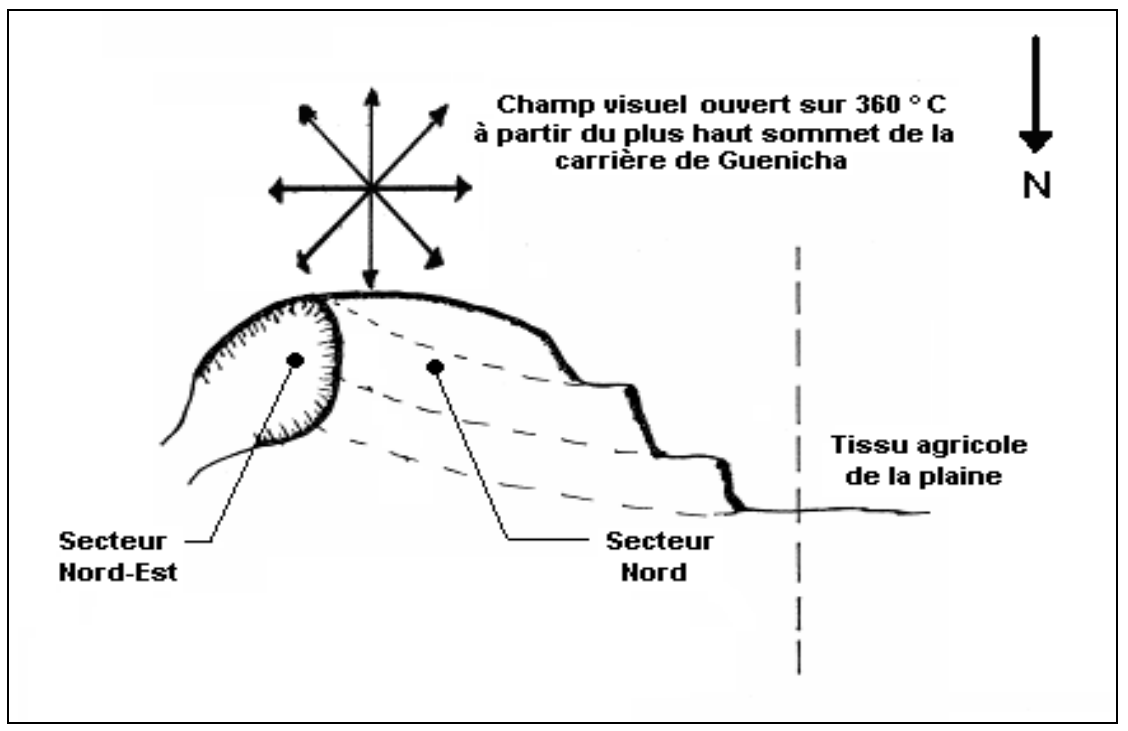

Figure 8 - Visual analysis from the site of Guenicha 
The views are characterized by a wide range of views and simultaneous:

- Over the whole of the plain north of Azzaba (Photo12 and 13 in figure 9);

- On the mountains of djebels Safia el Hajar Koudiats Attail and the North - East (Photo14 in figure 9).

- The forests and mountains of El djebels Ghedir, Dhira, Tenghout southwest (Figure 15 in figure.9).

- On forests Koudiat mzara, the Djebels Siafa Tenghout and south-east (Photo 16 in figure 9).

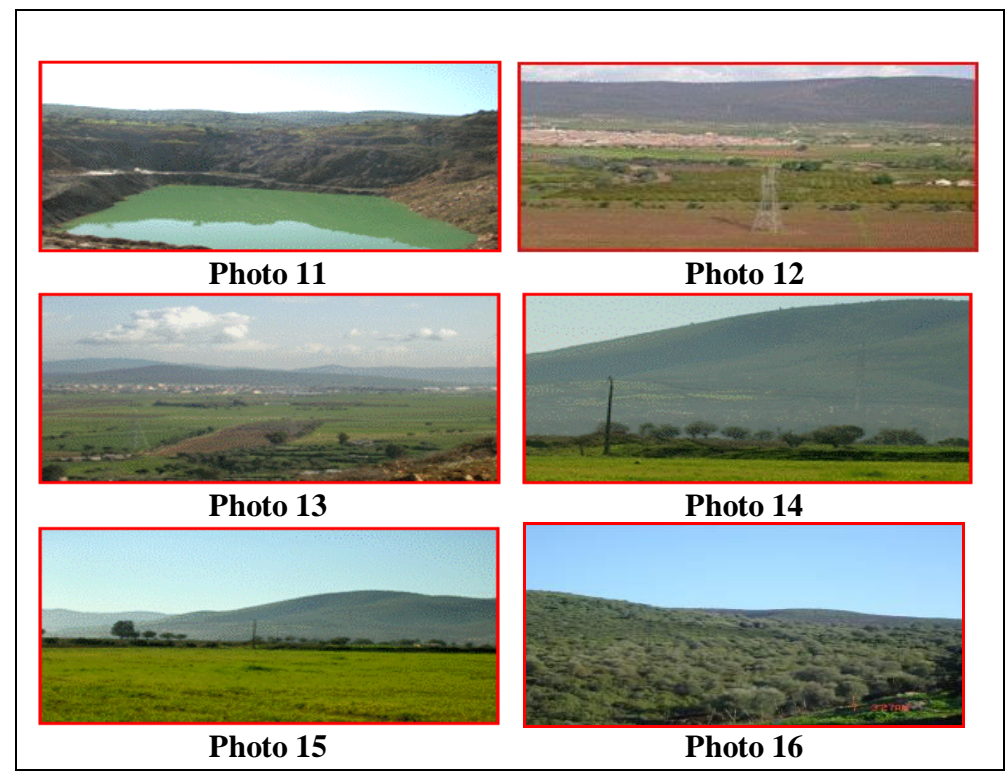

Figure 9 - Points of view from the career of Guenicha

\subsection{Summary of data and general guidelines on the type layout}

The site of the career of Guenicha is especially marked by rugged terrain that opposes the monotony of the plain. Its landscape study seems difficult for two reasons: - Difficult to find objective data abstraction that makes maximum aesthetic consideration

- The complexity of choosing among the many criteria for analysis, those that are most representative structure of subunit landscape.

The proposed landscaping that we propose will be based solely on the destination of each subunit, their visual quality and their relationship to the surrounding landscape (agricultural fabric of the plain, the village Menzel Bendich former Bayard and mountains that surround the study site). The study of soil and especially the landscape study allowed us to define the potential of the site while highlighting the various constraints. The study of visual site study to highlight the aesthetic

values of landscape scenes seen from different viewpoints chosen on this site. Indeed, all points of views from this career offer panoramic views of about a radius of $20 \mathrm{~km}$ over the plains and mountains all around him, these views are characterized by an open field of vision of $360^{\circ} \mathrm{C}$, thus giving their visual value. The soil survey has highlighted the erosion problems that plague this career. This erosion is mainly anthropogenic reflecting the fact that prolonged use of mechanical means and explosives that have considerable stripped and 
compacted soils. Thus this process is easily its continuity under the influence of climatic factors especially rainfall. Before the nature of the constraints revealed by the soil of the site, choosing the forestation of the career of Guenicha remains the most appropriate solution. It not only helps stabilize soils vis-à-vis the erosive action, but also to integrate this site into the surrounding landscape which is typical forest. Also in scope, this site could be dedicated to recreation and leisure for the population which lacks Azzaba place of recreation and leisure. To design a coherent and harmonious whole career with the plain, it is necessary to create visual transitions between different or other subunits and incorporate the surrounding landscape:

- Visually link the site Guenicha plain and surrounding hills mean by opening prospects by removing some grove especially at some orchard.

- Create links between farmland and orchards by channeled walkways on either side by roadside trees.

- Establish a visual barrier between the plant-like site to be developed (Guenicha career) and plant mercury (Fig.10).

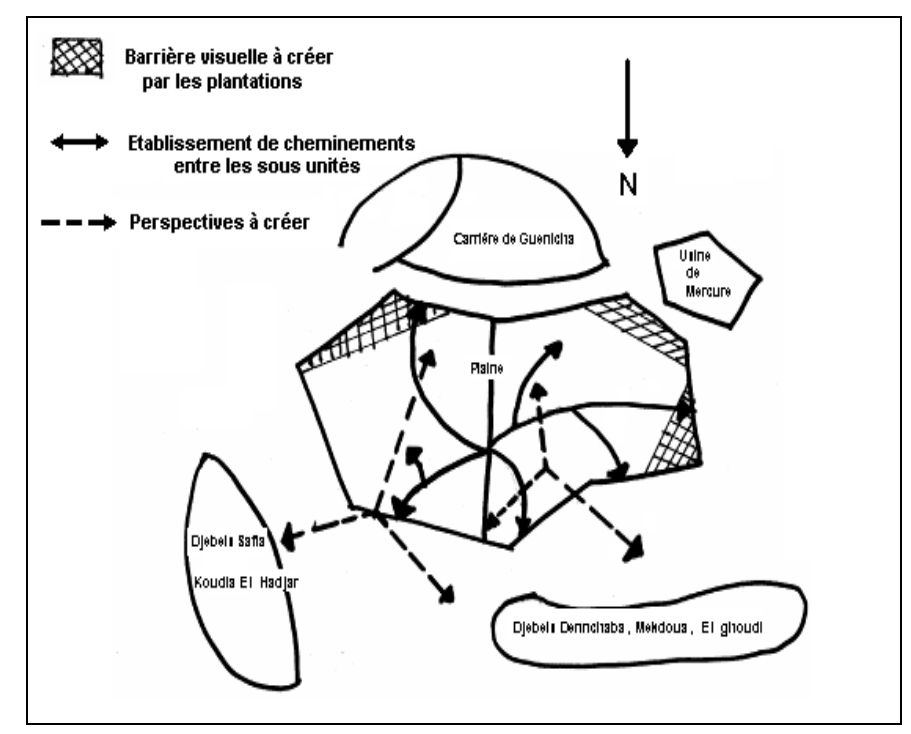

Figure 10 - Plan of intention

\section{Conclusion}

The study which we began concerning the landscaped potentialities and soil Guenicha's career is a stage indispensable to any proposals of its authorization. If such studies are done artfully and appropriately in developed countries, they remain virtually nonexistent in developing countries. Our work is a new experience that responds faithfully to the technique of empowerment (layout) free surfaces such as uneven career Guenicha. Objective analysis of data both on the landscape plan and soil we have focused on the type of authorization appropriate to our study area. Indeed, the career of this great potential Guenicha landscape. From this site, the visual field remains open $360^{\circ} \mathrm{C}$ with a fringe panoramic whole space occupied by the surrounding plain Azzaba and various mountain ranges. The north slope of the site is characterized by intense erosion and these grounds lost of their agricultural value and consequently become a limiting factor. It is thus necessary to begin (undertake) beforehand protective measures to stop any forms of degradation of the ground which 
deforms more the landscape. The development of a green forest would be a wise choice to stop erosion and removal of topsoil. Not only this green forest would fit best with the surrounding landscape but can fulfill a recreational and leisure for the population of the city of Azzaba which records a large deficit in green spaces.

\section{References}

[1] S.B.K. Clark, The value of landscape, Research news, Vol.1, (1974), p.16.

[2] J.F. Richard - Le paysage, analyse et synthèse. Contribution méthodologique à l'étude des milieux tropicaux (savanes et forêts de Côte d'Ivoire). - d'État (Géographie Physique), Ed. Paris, 1985.

[3] M. Cossin, H. Piegay, Vers une analyse qualitative des micro-paysages rivulaires : présentation des premiers résultats ", Actes des 3e rencontres de Théo Quant, 97, Besançon, France, 1999, p. 45-53.

[4] J.M. Besse, Voir la terre, six essais sur le paysage et la géographie, Actes Sud / ENSP / Centre du paysage, (2000), p. 99.

[5] P.H.Beckett, Interaction between knowledge and an esthetic appreciation, Landscape research news, Vol.1, Issue 8, 1974, 5 p.

[6] A.A. De Veer, P.A. Burrough, Physionomic landscape mapping in the natherlands. Landscape planning, Vol 5, Issue 1, 1978, $45-62$.

[7] C. S. Gagnon, L.N Tellier, K. D. Almeida, M.J Fortin,Territoires et communautés rurales : une complémentarité de méthodes pour l'étude du développement territorial viable de MRC québécoises». Recherches sociographiques. Vol XLVII, Issue, 3, 2006 p.597 - 612.

[8] B. Fischesser, M.F. Dupuis-Tate, Rivières et Paysages. Ed.La Martinière, 2006.

[9] D. Fadel, Traitement d'une zone suburbaine en forêt de loisirs dans la région de Skikda. Mém. Ing. Etat. INA, 1979, 95 p.

[10] M. Griselin,S. Ormaux, Analyse systématique du paysage visible à partir de photographies au sol : exemple du bassin Loven Est, baie du Roi, Svalbard, Actes des 4es rencontres de Théo Quant, 99, Besançon, France, 2001, p. 63-72.

[11] H. Davodeau, La sensibilité paysagère à l'épreuve de la gestion territoriale, Les Cahiers de Géographie du Québec, Vol 49, Issue 137, 2005, p.177-189.

[12] H. Davodeau, Public policies and landscapes: the issue of a change in scales, in Proceedings 18th international annuel ECLAS, Belgrade, Serbie, 2007, p.155-156.

[13] H. Craik, Individual variations in landscape description. Ed. Stroudsburg (Pennsylvania), Dowden, Hutchinson and Ross, 1975.

[14] M.J. Fortin, Les analyses paysagères dans l'évaluation environnementale au Québec : paradigmes en action, Les Annales des Ponts et Chaussées, Ed. Scientifiques Elsevier, Paris, [15] A. Graïri, Contribution à l'aménagement du site de Sidi Achour, zone suburbaine de la ville d'Annaba en forêt récréative. Mém. Ing. Etat. Ecologie \& Env. Univ. Annaba, 2002,75 p.

[16] R. Soualem R., (2003) - Quantification qualitative des paysages autour du tronçon autoroutier El Hadjar - Annaba. Mém. Ing. Etat. Ecologie \& Env. Univ. Annaba, 2003, 35 p.

[17] R. Hameg, Quantification des groupements paysagers périphériques au tronçon autoroutier Annaba - Berrahal - Annaba. Mém. Ing. Etat. Ecologie \& Env. Univ. Annaba, 2005, $45 \mathrm{p}$.

[18] A.A, Carlson, On the possibility of quantifying, scenic beauty, Landscape planning, Vol.4, Issue 2, 1977, p. 131-172.

[19] M.J. Fortin, Landscape, an interpretative framework for a reflexive society, Ed. Quae, Versailles, 2008.

[20] D. Fadel, Quantification des groupements paysagers périphériques au tronçon autoroutier Annaba - El Hadjar -Annaba, Actes du colloque Environnement et Transports dans des contextes différents, Ghardaïa, Algérie, 2009, p. 130-141.

The work was carried out at the University of Souk - Ahras - Algeria 